\title{
METODE ANALISIS SPACE SYNTAX PADA PENELITIAN INTERAKSI KOTA MULTIBUDAYA
}

\author{
Cynthia Puspitasari \\ Mahasiswa Program Studi Arsitektur, Institut Teknologi Bandung; \\ Staf Program Studi Arsitektur Universitas Pancasila \\ cynthia.puspitasari@gmail.com
}

\begin{abstract}
Multicultural city is a phenomenon city that is formed from a variety of different cultures within the city. In recent years, this condition has become a major problem that does not only occur in cities in Indonesia that have diverse ethnicities, but also occur in cities in developed countries such as the United States, United Kingdom and other European countries. Immigrants from other nations encourage new cultural communities in the city that cause the presence of certain cultures. Is there any interaction between those cultural communities? What is the impact on urban spaces? How do you measure the interaction? This study tries to explore analytical methods to measure interactions in multicultural city spaces. The method used is qualitative explorative which describes the analysis of Space Syntax by using DepthMapX software. The results of this paper are a clear and detailed explanation of the method of analyzing space syntax to help the benefits of spatialising multicultural concepts within cities.
\end{abstract}

Key Words: city, multicultural, interaction, analysis, syntax space.

\begin{abstract}
Abstrak : Kota multibudaya merupakan fenomena wujud kota yang terbentuk dari beragam perbedaan budaya di dalam kota. Kondisi tersebut, dalam beberapa tahun terakhir menjadi isu besar yang bukan hanya terjadi pada kota-kota di Indonesia yang memiliki keragaman etnis, namun juga terjadi pada kota-kota di negara maju seperti Amerika Serikat, Inggris dan negara Eropa lainnya. Kedatangan imigran dari bangsa lain mendorong munculnya komunitas budaya baru di dalam kota yang mengakibatkan hadirnya kantong budaya tertentu. Adakah interaksi di antara komunitas budaya tersebut? Apakah dampaknya pada ruang-ruang kota? Bagaimana cara mengukur interaksi tersebut? Penelitian ini bertujuan mengeksplorasi metode analisis untuk mengukur interaksi pada ruang-ruang kota multibudaya. Metode yang digunakan adalah kualitatif eksplotarif yang menjabarkan analisis Space syntax dengan bantuan perangkat lunak DepthMapX. Hasil dari tulisan ini adalah gambaran jelas dan mendetail mengenai metode analisis Space syntax beserta manfaatnya dalam membantu menspasialisasikan konsep multibudaya dalam kota.
\end{abstract}

Kata Kunci : kota, multibudaya, interaksi, analisis, space syntax.

\section{PENDAHULUAN}

Kota multikultural atau multibudaya terbentuk karena adanya pluralisme di dalam institusi dan struktur kota. Plurarisme muncul karena adanya penerimaan terhadap keberagaman budaya atau agama yang berbeda dan saling berinteraksi. Pada awalnya, di perkotaan muncul keragaman etnis yang didorong oleh adanya kegiatan imigrasi di masa lalu. Kemudian kegiatan imigrasi tersebut mendorong hadirnya berbagai budaya atau agama di ruang-ruang kota.

Kota-kota yang banyak terlibat dalam perdagangan maritim di masa lalu pada umumnya telah mengalami kondisi multibudaya sejak lama. Sebut saja kota-kota di Indonesia yang telah menerima kedatangan bangsa asing sejak berabad-abad lalu, sebagai dampak dari perdagangan laut. Bangsa Cina, India, Arab dan Eropa menjadi etnik budaya baru yang masuk dan menetap di bagian-bagian dari ruang kota. Pada beberapa kota, komunitas tersebut masih bertahan dalam enklave atau kantong budaya yang jelas, seperti halnya kampung Cina (Pecinan), kampung Arab, atau kampung lokal berbasis budaya lainnya (kampung nelayan, kampung pembatik, kampung adat).

Dalam rentang waktu yang lama, enklave budaya yang awalnya terkotak-kotak, karena adanya kebutuhan, mulai terjadi interaksi baik antar individu maupun antar komunitas budaya. Kota kemudian menjadi wadah permersatu dan pengikat bagi komunitas budaya-budaya tersebut dalam berinteraksi dan berbaur. Lalu bagaimana interaksi dan pertemuan antar budaya tersebut 
dapat terjadi di dalam ruang kota? Bagaimana wujud interaksi tersebut?

Melalui analisis Space syntax penelitian dititikberatkan pada proses identifikasi pergerakan dan perilaku dalam ruang kota berdasarkan pertemuan antar kehidupan enklaveenklave budaya dan pola keterhubungan yang terjadi di antara enklave tersebut. Penelitian ini akan membahas bagaimana metode analisis Space syntax dapat mengungkapkannya melalui observasi konektivitas antar enklave dan integrasi ruang kota.

\section{INTERAKSI KOTA MULTIBUDAYA}

Kota ada sebelum adanya kedatangan dari imigran yang membawa identitas dan budaya mereka. Sejarahnya, geografi, organisasi ekonomi, tradisi budaya dan struktur sosial seperti halnya tatanan politik didirikan melalui proses yang panjang. Perbedaan norma dan praktik harus diintegrasikan menjadi kesatuan budaya warga dan nilai-nilai yang umum. Dinamisme budaya dan perbedaan sosial serta integrasi menjadi tantangan bagi studi kota multibudaya yang di dalamnya terdapat kantongkantong atau enklave berbasis etnik atau budaya.

Untuk memahami interaksi antar budaya mula-mula dilihat dari keterhubungan antar enklave budaya dengan jaringan utama dalam kota. Amin (2012) menyatakan konsep 'sivilitas ketidakpedulian' sebagai politik yang diusulkannya hidup bersama, idenya bukan untuk menentang keberadaan kantong spasial dalam struktur kota, melainkan untuk menekankan perlunya menghubungkan lokal ke jaringan global melalui ruang yang tumpang tindih. Persinggungan antar enklave dan pola kegiatan komunitas budaya dapat menimbulkan pertemuan dalam bentuk ruang bersama. Untuk mengukur pola ruang tersebut pergerakan budaya menjadi faktor penting yang harus diobservasi secara mendalam.

Selama rentang waktu yang panjang fisiologi dan psikologi manusia adalah strategi fisik yang umum digunakan untuk membentuk kota (Lynch, 1981). Pergerakan manusia sebagai pelaku budaya dalam melakukan kegiatan budaya menjadi unsur penting dalam menciptakan pola spasial kota. Kota dapat dianggap sebagai fenomena spasial yang dibentuk untuk mengakomodasi perbedaan dan kompleksitas (Bridge \& Watson, 2003). Artinya pola spasial kota selain terbentuk dari pergerakan manusia, juga dipengaruhi oleh adalah beragam tipe pergerakan yang kompleks dari komunitas budaya berbeda di dalamnya.

Sarraf (2015), dalam disertasinya Spatiality of Multiculturalism, menjelaskan bahwa hubungan antara spasial yang meresap mengacu pada situasi spasial dan fluiditas masyarakat sebagai konsep sosial. Inti argumennya adalah bahwa bentuk perkotaan dapat meningkatkan kelangsungan hidup berdampingan dan multiplisitas dengan memperluas aliran gerakan dari satu kelompok spasial ke yang lain. Sederhananya, ruang publik lingkungan bertemu jaringan latar depan melalui ruang tumpang tindih yang secara bersamaan tumpang tindih dengan lingkungan lain. Pervasif ruang secara spatial dari ruang yang tumpang tindih seperti itu membuat kehadiran bersama individu dari lingkungan yang berbeda lebih mungkin terjadi di dalamnya. Menarik individu-individu dari ruang enklave (atau lingkungan) yang berbeda ke ruang publik sebenarnya menciptakan apa yang disebut copresence of heterogenity in space. Jelaslah bagaimana situasi ini kemudian membuktikan struktur non-korespondensi antara demarkasi spasial dan pengelompokan sosial.

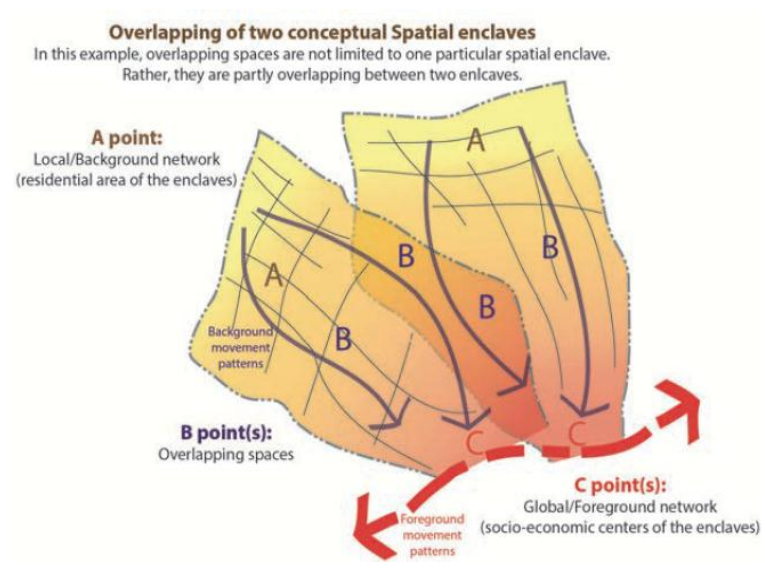

Gambar 1. Konsep Spasial Pergerakan dan Interaksi pada Dua Enklave Budaya Sumber: Sarraf, 2015 
Untuk membuat argumen ini lebih transparan, diskusi berlanjut dengan contoh konseptual yang diartikulasikan terutama menggunakan teori sintaksis ruang (Space syntax). Contoh ini menggambarkan semacam kasus ekstrem, pada tingkat abstrak, yang dapat membantu menyampaikan gagasan keseluruhan.

\section{ENKLAVE ETNIK}

Istilah enklave atau kantong etnis pertama kali digunakan pada The Treaty of Madrid (1526). Menurut Digby (2006), enklave berarti 'sesuatu yang terbatas dan terkonsentrasi'. Ini berarti bahwa enklave memiliki batas, dan terbatas pada area cakupan tertentu. Widmer \& Klingele (2000) menjelaskan bahwa ada banyak contoh kantong di dunia ini, dan itu tidak terbatas pada etnis saja. Ini berkisar dari kelompok atau komunitas orang yang berbeda sebagai penghuninya diklasifikasikan berdasarkan etnis, standar hidup, agama, dan kecenderungan seksual. Singapura adalah contoh negara yang memiliki banyak kantong etnik seperti Chinatown, Little India, kampung Arab dan Bugis Village. Daerah kantong etnik ada di seluruh dunia terutama negara yang di dalamnya terdapat imigran yang berasal dari negara lain.

Alejandro Portes adalah salah satu cendekiawan yang mempelopori bahasan mengenai enklave etnis. Ia dan Kenneth Wilson (1980) membentuk teori enklave etnis sambil mengamati imigran Kuba di Miami. Mereka menyimpulkan bahwa imigran tidak segera berasimilasi ke dalam "ekonomi perifer" (ekonomi utama sebuah kota) dan malah dibantu oleh keberadaan ekonomi enklave (sub-ekonomi imigran yang berbagi bisnis umum, ruang, dan jaringan). Jadi, dalam melalukan migrasi ke wilayah baru, sebuah etnis tidak langsung berinteraksi secara ekonomi dengan penghuni lokal, melainkan membuat enklave-enklave mereka sendiri yang di dalamnya terdapat kegiatan ekonomi mereka sendiri. Namun, daerah kantong etnis juga dapat dibentuk karena adanya pemisahan, diskriminasi dan pengucilan negara tuan rumah kepada para imigran. Ini mungkin disebabkan oleh persepsi orang-orang yang berpikir bahwa imigran merupakan ancaman bagi mereka dalam hal keselamatan, kondisi kesehatan, kesempatan kerja dan urusan agama.

Pertemuan berbagai budaya yang berbeda yang kemudian berinteraksi dan mengakibatkan adanya percampuran budaya. Pada beberapa kasus dapat terjadi akulturasi tetapi ada juga yang berasimilasi budaya. Pada penelitian ini, fokus budaya diarahkan pada pertemuan antar budaya yang terjadi di kota multikultural. Pada kantongkantong budaya, pelaku budaya masing-masing berkegiatan budaya dalam keseharian mereka. Kegiatan budaya yang dilakukan oleh suatu komunitas dinamakan praktik budaya.

\section{PRAKTIK BUDAYA}

Dalam ruang kota, praktik budaya tidak hanya dilakukan oleh budaya yang sejenis atau tunggal. Praktik-praktik budaya di lingkungan perkotaan dibangun oleh beragam budaya yang saling bercampur dan berinteraksi. Perwujudan praktik budaya diekspresikan di dalam ruangruang perkotaan. Giddens (1979), mengungkapkan tentang teori strukturasi berdasarkan pada perbedaan antara agency dan structure. Agency hanyalah kapasitas untuk mengubah dunia. Structure, di sisi lain, adalah properti terorganisir dari sistem sosial yang dibentuk oleh aturan dan sumber daya, kerangka kerja di mana kapasitas kita direalisasikan atau tidak. Dari pandangan ini arsitektur dapat dianggap sebagai bentuk structure, dan aksi sosial yang dibingkai sebagai bentuk agency.

\section{SPACE SYNTAX}

Metode analisis Space Syntax dikembangkan oleh Bill Hillier beserta rekanrekannya di University College London dan telah diterapkan dalam berbagai studi perkotaan sejak tahun 1980-an. Metode ini terdiri dari penghitungan dari hubungan spasial konfiguratif dalam lingkungan binaan.

Menurut Hillier (2007), metode ini melibatkan empat elemen penting dalam analisis perkotaan, yakni:

1. Space syntax beroperasi dengan definisi ruang kota yang ringkas

2. Space syntax menawarkan serangkaian teknis untuk menganalisis kota sebagai jaringan 
ruang yang dibentuk oleh penempatan, pengelompokan, dan orientasi bangunan

3. Space syntax melibatkan seperangkat teknis untuk mengamati bagaimana jaringan ruang kota berhubungan dengan pola-pola fungsional, seperti gerakan, penggunaan lahan, diferensiasi kawasan, pola migrasi, dan bahkan kesejahteraan sosial dan perasaan

4. Space syntax dibuat berdasarkan hasil empiris yang timbul dari aspek-aspek yang memungkinkan untuk mengembangkan seperangkat teori tentang bagaimana jaringan ruang kota berhubungan secara umum dengan faktor sosial, ekonomi dan kognitif yang membentuknya, serta bagaimana mempengaruhinya

Dalam konteks ruang perkotaan, hubungan ini terwujud dalam interaksi ruang yang dapat diidentifikasi dari adanya pergerakan dari satu ruang ke ruang lainnya. Dengan objek berupa ruang, kekuatan interaksi ini dipengaruhi oleh properti morfologi sistem ruang tersebut, antara lain guna lahan, struktur bangunan, pola kapling dan pola jaringan jalan (Conzen dalam Carmona et al, 2003).

Di antara properti morfologi tersebut, pola jaringan menjadi komponen penting dalam perancangan kota karena mempengaruhi aspek kualitas ruang berupa permeabilitas dan aksesibilitas (Carmona et al, 2003). Permeabilitas merupakan parameter yang mengukur sejauh mana konfigurasi ruang menyediakan pilihan dalam menempuh perjalanan dan aksesibilitas adalah parameter yang diukur dari interaksi antara individu dengan sistem ruang. Hillier dalam Carmona et al (2003) menjelaskan bahwa pola dan intensitas pergerakan individu sangat dipengaruhi oleh konfigurasi ruang, bahkan struktur ruang dapat dianggap sebagai penentu tunggal yang paling mempengaruhi pergerakan dalam ruang. Untuk mengukur interaksi dalam konfigurasi ruang, Space syntax mempergunakan beberapa dimensi yang diukur dengan mempergunakan konsep jarak topologi (topological distance) yang disebut kedalaman (depth).

Konsep jarak topological distance dipergunakan dalam analisis garis aksial (axial line), untuk menghitung hubungan antara garisgaris yang saling berpotongan atau saling bertemu pada verteks (vertex) dimana dalam analisis ini ruang direpresentasikan dalam bentuk garis (axial line). Depth sebagai dimensi jarak kemudian dipergunakan sebagai satu-satunya ukuran dalam perhitungan konektivitas dan integrasi (connectivity dan integration) (Siregar, 2014).

\section{METODE ANALISIS SPACE SYNTAX}

1. Connectivity (Konektivitas)

Analisis menggunakan metode Space syntax connectivity, yakni dimensi yang mengukur properti lokal dengan cara menghitung jumlah ruang yang secara langsung terhubung dengan masing-masing ruang lainnya dalam suatu konfigurasi ruang (Hillier et al (1993) dan Hillier et al (1987). Disebut properti lokal karena informasi mengenai hubungan ruang dapat secara langsung diamati dari ruang pengamatan, sementara ruang-ruang yang tidak dapat diobservasi dari ruang pengamatan tidak akan diperhitungkan. Jumlah ruang yang terhubung dihitung dengan mempergunakan konsep jarak yang disebut kedalaman atau depth. Dengan demikian, dikatakan terhubung secara langsung apabila hanya memiliki jarak sebesar 1 langkah atau 1 step depth.

Pengukuran konektivitas dilakukan untuk menemukan tingkat interaksi setiap ruang terhadap ruang-ruang yang berada di dekatnya. Kegunaan utama nilai konektivitas adalah untuk mengukur tingkat intelligibility dengan cara mengkorelasikan nilai konektivitas dengan nilai integrasi perhitungan nilai konektivitas untuk setiap ruang dilakukan dengan menjumlahkan semua ruang yang terhubung secara langsung dengan ruang pengamatan (Siregar, 2014). 


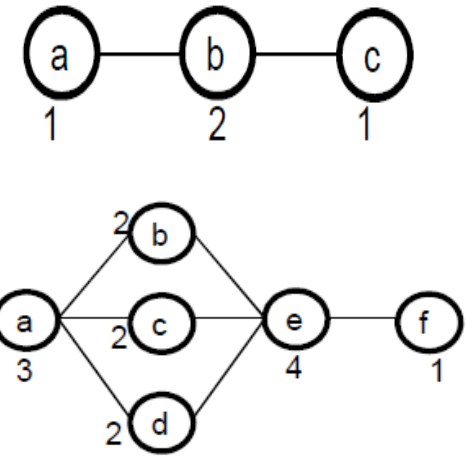

Gambar 2. Perhitungan Nilai Konektivitas Sumber: Siregar, 2014

\section{Integration (Integrasi)}

Integrasi adalah dimensi yang mengukur properti global berupa posisi relatif dari masingmasing ruang terhadap ruang-ruang lainnya dalam suatu konfigurasi ruang (Hillier et al, 1987 dan Hillier et al, 1993). Disebut properti global karena perhitungan nilai integrasi tidak hanya melibatkan ruang-ruang yang secara langsung terkoneksi, tetapi juga ruang-ruang lainnya yang terkoneksi tidak secara langsung dengan ruang pengamatan. Atau dengan kata lain, perhitungan ini juga melibatkan ruang-ruang yang tidak dapat diobservasi dari ruang pengamatan, dimana penilaian integrity suatu ruang akan melibatkan seluruh ruang lainnya dalam suatu konfigurasi ruang (Hillier et al, 2007). Integrasi merupakan salah satu pengukuran yang penting dalam space syntax sebab dengan metode pengukuran ini, analisis terhadap konfigurasi ruang sebagai sebuah sistem dapat dilakukan.

Posisi relatif ruang dihitung dengan mempergunakan metode step depth. Dari posisi relatif ini dapat diketahui seberapa jauh (step depth) sebuah ruang dari ruang-ruang lainnya. Ruang yang memiliki nilai integrasi yang tinggi (kedalaman / depth yang rendah) dianggap memiliki interaksi yang tinggi secara relatif terhadap ruang-ruang lainnya pada konfigurasi tersebut, atau dengan kata lain terkoneksi secara baik ke ruang pengamatan (Hillier dan Hanson, 1984). Semakin banyak ruang yang yang terkoneksi secara langsung dengan ruang pengamatan maka semakin tinggi pula nilai integrasi ruang tersebut, sebaliknya semakin banyak ruang antara maka semakin rendah pula nilai integrasi ruang tersebut (Siregar, 2014). a)

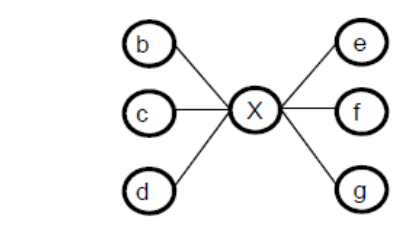

b)

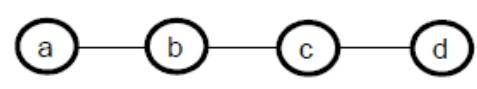

Gambar 3. Perhitungan Nilai Integrasi

a) Nilai Integrasi Tinggi

b) Nilai Integrasi Rendah

Sumber: Siregar, 2014

Integrasi lebih lanjut dipergunakan untuk mempelajari kekompakan ruang dalam sistem ruang. Ruang dengan nilai integrasi yang tinggi dapat diinterpretasikan sebagai ruang yang memiliki derajat kesatuan yang tinggi terhadap konfigurasi ruang secara keseluruhan (global), demikian sebaliknya, ruang dengan nilai integrasi yang rendah akan cenderung memisahkan diri dalam konfigurasi.

\section{METODE ANALISIS SPACE SYNTAX PADA PENELITIAN INTERAKSI KOTA MULTIBUDAYA \\ Pengumpulan Data}

Untuk mendukung proses analisis Space syntax, diperlukan beberapa metode pengumpulan data yang mengarah pada proses pembuatan peta dasar dan data pendukung dalam peta. Untuk itu dilakukan pengumpulan data yang meliputi wawancara, dokumentasi dan observasi untuk memenuhi kebutuhan data tentang structure dan agency (praktik budaya) serta identifikasi morfologi kawasan untuk membuat peta dasar.

Teknik wawancara dilakukan dengan mengambil perwakilan setiap komunitas budaya, misalnya ketua RT di Pecinan, kampung Arab dan kampung Nelayan. Partisipan kemudian berkembang pada banyak partisipan dari masingmasing budaya untuk mengetahui titik-titik lokasi kegiatan berdasarkan waktu kegiatan, pelaku dan tempat. Contoh hasil wawancara dapat dibuat dalam format tabel seperti di bawah ini. 
Tabel 1. Contoh Pengumpulan Data untuk Menentukan Titik Kegiatan Space Syntax

\begin{tabular}{|c|c|c|c|c|}
\hline Kegiatan dan Waktu & Lokasi Asal & Lokasi Tujuan & Pelaku & Jadwal \\
\hline \multicolumn{5}{|l|}{ Kegiatan Harian } \\
\hline Bekerja & Permukiman & Toko & Warga laki-laki & Senin-Minggu \\
\hline Bekerja & Permukiman & Kantor & Warga laki-laki & Senin-Jumat \\
\hline Sekolah & Permukiman & Sekolah & Siswa & Senin-Sabtu \\
\hline Shalat 5 waktu & Permukiman & Masjid & Warga laki-laki & Senin-Minggu \\
\hline Belajar/mengajar & Permukiman & Pesantren & Ustadz, santri & Senin-Sabtu \\
\hline Belanja & Permukiman & Pasar & \multicolumn{2}{|c|}{ Warga, pendatangSenin-Minggu } \\
\hline Belanja & Permukiman & Toko & \multicolumn{2}{|c|}{ Warga, pendatangSenin-Minggu } \\
\hline \multicolumn{5}{|l|}{ Kegiatan Mingguan } \\
\hline Shalat Jumat & Permukiman & Masjid Mudhor & Warga laki-laki & Jumat, $12.00-12.30$ \\
\hline \multirow[t]{2}{*}{ Rekreasi } & Permukiman & Pantai & Keluarga & Sabtu, Minggu \\
\hline & Permukiman & Alun-alun & Keluarga & Sabtu, Minggu \\
\hline \multicolumn{5}{|l|}{ Kegiatan Khusus } \\
\hline Tarawih & Permukiman & Masjid Mudhor & Warga laki-laki & 1 bulan, $19.00-21.0$ \\
\hline Idul Adha & Permukiman & Alun-alun & Keluarga & $06.30-07.30$ \\
\hline Kurban & Permukiman & Masjid Mudhor & Warga laki-laki & $09.00-17.00$ \\
\hline Idul Fitri & Permukiman & Alun-alun & Keluarga & 06.30-07.30 \\
\hline $\begin{array}{l}\text { Festival bubur } \\
\text { Mudhor }\end{array}$ & Permukiman & Masjid Mudhor & $\begin{array}{l}\text { Warga laki-laki, } \\
\text { pendatang }\end{array}$ & 1 bulan, $16.00-17.0$ \\
\hline
\end{tabular}

Hasil wawancara pada tabel di atas, diterapkan pada semua enklave budaya yang akan diamati. Hasilnya dapat memberikan data titik pergerakan dari asal ke tujuan berdasarkan waktu.

Pengambilan data lapangan dilakukan dengan cara peneliti harus memantau aspek structure dan mengidentifikasi pergerakan budaya aspek agency dari masing-masing komunitas budaya. Peralatan yang diperlukan untuk observasi berupa kamera, buku catatan, alat tulis dan aplikasi Google Earth Pro serta Google Street View.

Pada proses identifikasi lapangan dilakukan dengan menggambar ulang morfologi kota yang terdiri dari layer jaringan jalan, pola kapling, bangunan, ruang terbuka, sungai/laut dan sebagainya dengan bantuan AutoCAD. Proses identifikasi dilakukan dengan observasi lapangan, pengambilan foto dan pencatatan. Aplikasi Google Earth Pro serta Google Street View membantu proses validasi atau kebenaran peta secara aktual. Data akhir dari proses identifikasi adalah berupa peta dalam format CAD (dxf).

\section{Pengolahan Data}

Dalam menganalisis interaksi kota multibudaya, analisis Space syntax dengan pengukuran konektivitas dan integrasi di ruang kota akan sangat membantu. Dalam prosesnya, digunakan perangkat lunak DepthmapX, yakni aplikasi open source buatan University College London. Aplikasi ini berkerja dengan sistem verteks yang meliputi, titik, garis dan gambar 2 dimensi.

\section{Analisis Connectivity (Konektivitas)}

Pada analisis konektivitas, yang ingin diketahui adalah pergerakan lokal pada satu kelompok komunitas. Langkah pertama adalah menentukan enklave apa yang akan diamati terlebih dahulu. Sebagai contoh, pada suatu kota multibudaya terdapat dua enklave dominan, yakni enklave budaya $\mathrm{X}$, enklave budaya $\mathrm{Y}$ dan ekitarnya adalah budaya lokal. Analisis secara satu persatu.

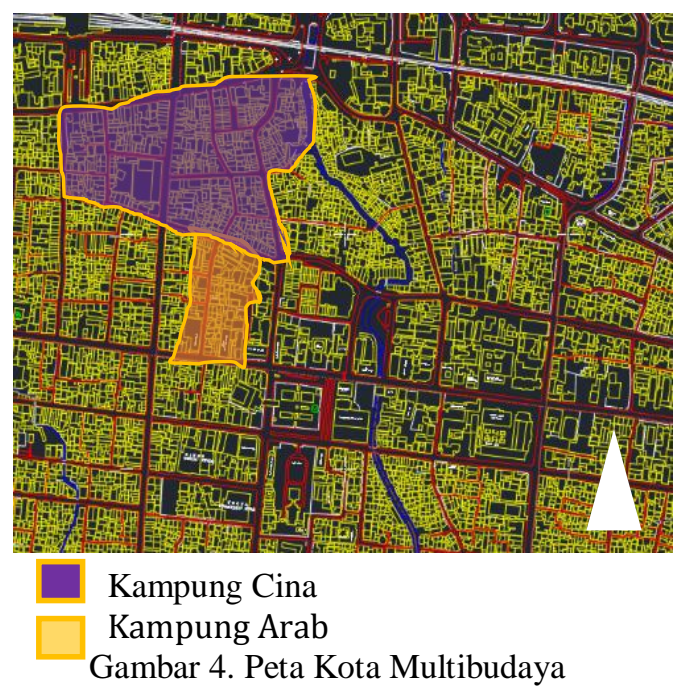

Bedakan pengamatan berdasarkan waktu kegiatan: sehari-hari/mingguan/tahunan/khusus. Data titik-titik budaya harus dipersiapkan dari hasil observasi dan wawancara, misalnya untuk kegiatan sehari-hari, menggunakan titik lokasi permukiman, titik lokasi kegiatan pekerjaan A, B dan C. Kemudian, perlu ditentukan radius pengukuran di mana semua titik masuk ke dalamnya, misalnya 2000 meter. Peta dasar format (dxf) sudah disiapkan (lengkap dengan layer) dibuka dalam DepthmapX. 


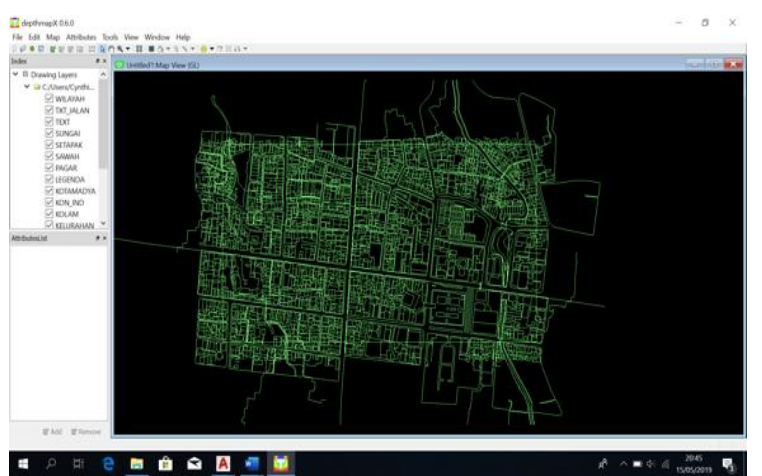

Gambar 5. Peta Siap Olah dalam DepthMapX

Konektivitas diproses dengan DepthmapX. Hasilnya dapat berupa peta garis aksial. Langkahnya dengan menarik garis konektivitas dari titik permukiman ke titik kegiatan secara manual hingga muncul garis berwarna-warni. Warna peta akan menentukan derajat konektivitas. Pada peta garis aksial, warna merah merupakan warna dengan nilai konektivitas tertinggi, artinya pada sirkulasi yang garisnya berwarna merah merupakan ruang dengan pola konektivitas tertinggi sedangkan warna biru adalah yang terendah.

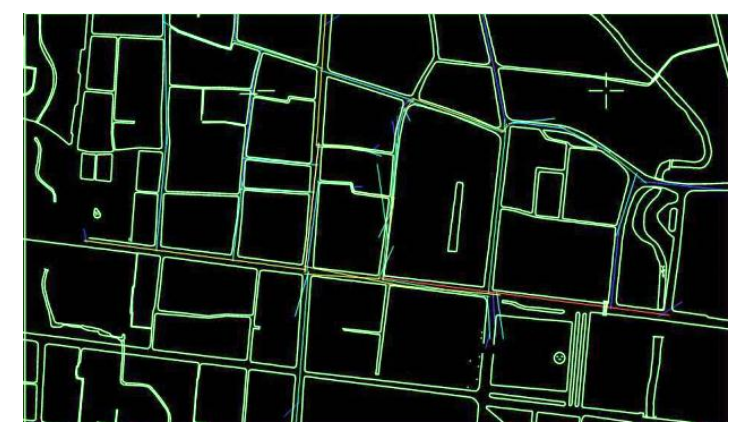

\section{Keterangan}

- Nilai konektivitas 1

- Nilai konektivitas 2

- Nilai konektivitas 3

Nilai konektivitas 4

- Nilai konektivitas 5

- Nilai konektivitas 6

Gambar 6. Hasil Peta Garis Aksial

Nilai tersebut lebih mudah dibaca dalam peta grafik yang menunjukan nilai kedalaman. Nilai kedalaman yang tinggi menunjukan konektivitas yang tinggi dan begitu juga sebaliknya.

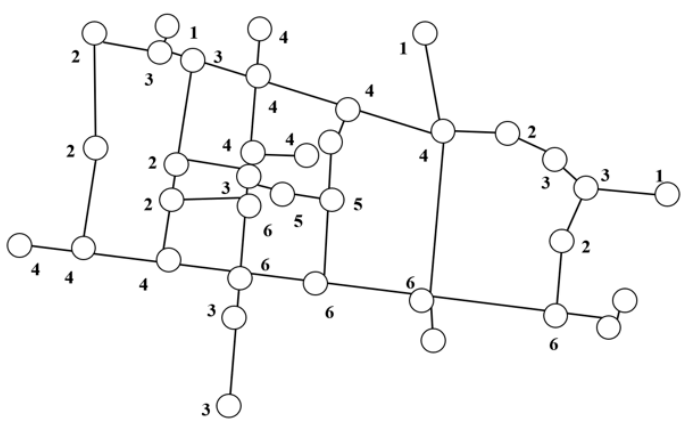

Gambar 7. Hasil Peta Grafik Aksial

Hasil peta analisis dari semua enklave pada waktu yang bersamaan ditumpuk (overlay) pada koordinat yang sama dengan menggunakan bantuan Adobe Photoshop. Garis yang bertumpuk akan menunjukan adanya pertemuan dan interaksi antar kelompok budaya di ruang tertentu.

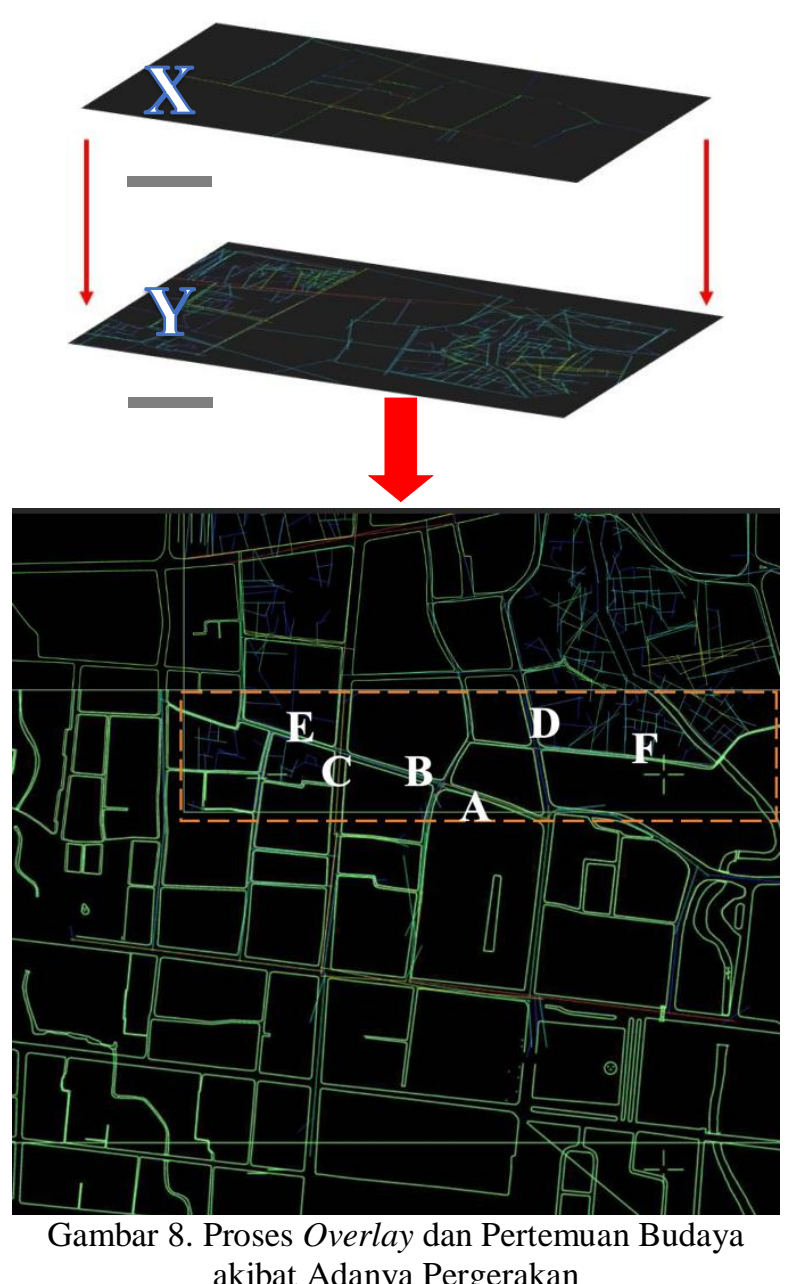

Hasil overlay dari dua enklave menunjukkan terdapat pertemuan antara pergerakan keseharian dari komunitas budaya $\mathrm{X}$ dan Y. Bila diteliti lebih mendalam, titik 
pertemuan terjadi pada jaringan jalan perbatasan enklave. Nilai konektivitas interaksi dapat diukur dari nilai kedalaman garis pertemuan. Sedangkan untuk mengetahui pertemuan pada saat kegiatan apa dari masing-masing komunitas dapat diliat dari informasi titik-titik kegiatan, seperti tabel di bawah ini.

Tabel 2. Contoh Hasil Pengukuran Interaksi pada Ruang Kota dengan Space Syntax

\begin{tabular}{|l|l|l|}
\hline Titik Interaksi & $\begin{array}{c}\text { Nilai } \\
\text { Konektivitas }\end{array}$ & $\begin{array}{c}\text { Jenis Kegiatan } \\
\text { Penyebab Interaksi }\end{array}$ \\
\hline A Kavling .. & 4 & Ekonomi \\
\hline B Jalan ... & 1 & Sirkulasi \\
\hline C Jalan ... & 2 & Sirkulasi \\
\hline $\begin{array}{l}\text { dan } \\
\text { seterusnya }\end{array}$ & & \\
\hline
\end{tabular}

Sumber: Hasil Analisis, 2019

Selain terjadi di luar enklave, interaksi juga bertemu pada bagian kecil dari kawasan X. Ini menunjukkan pertemuan antar budaya terjadi karena budaya yang satu dapat mengakses enklave budaya lain. Baik disebabkan kegiatan sirkulasi, kegiatan ekonomi atau kegiatan lainnya.

Dari hasil tersebut, diobservasi ruangruang interaksi yang terbentuk. Kemudian, dari garis-garis perpotongan dapat diketahui bentukan ruang-ruang baru yang dapat diarahkan pada pembentukan ruang publik sebagai melting pot berbagai budaya.

\section{Analisis (Integration) integrasi}

Proses analisis kedua adalah untuk mengetahui interaksi kawasan kota pada skala global. Analisis ini dinilai melalui aspek global dan jaringan jalan terhadap titik-titik di sekitarnya.

Tentukan titik pengamatan global yang menjadi sentral bagi kawasan, dalam hal ini titik yang diuji bisa alun-alun atau jalan utama kota. Tentukan radius pengukuran di mana semua enklave masuk ke dalamnya, misalnya 20000 meter. Peta dasar format (dxf) sudah disiapkan (lengkap dengan layer) dibuka dalam DepthmapX.

Integrasi dapat diproses dengan DepthmapX. Hasilnya dapat berupa peta garis aksial. Warna peta akan menentukan derajat integrasi. Pada peta garis aksial, warna merah merupakan warna dengan nilai integrasi tertinggi, artinya pada sirkulasi yang garisnya berwarna merah merupakan ruang dengan pola integrasi tertinggi sedangkan warna biru adalah yang terendah.

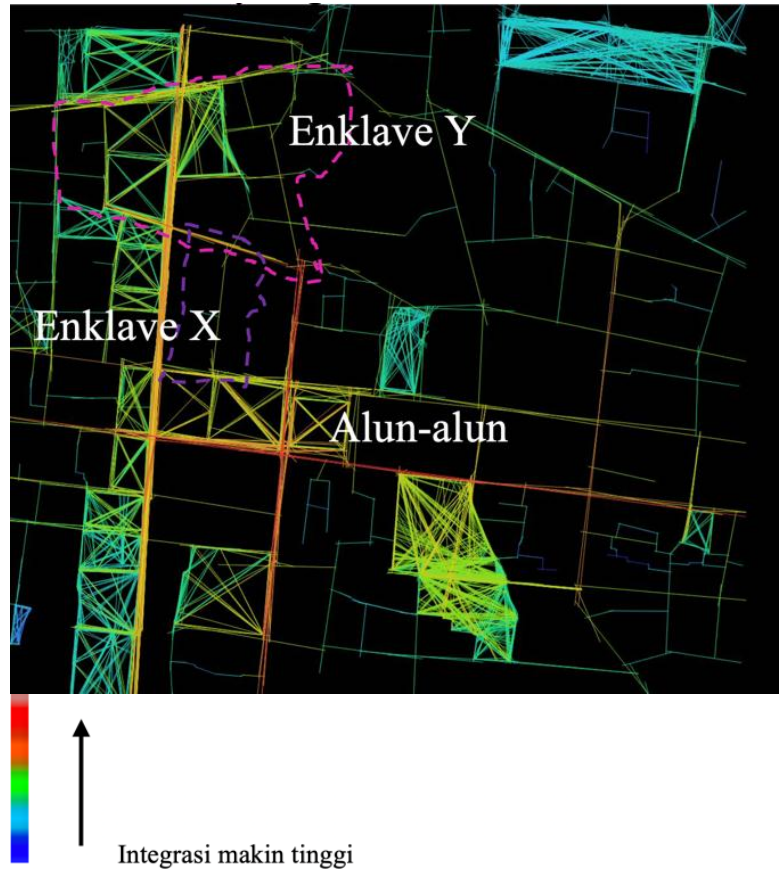

Gambar 9. Hasil Pengukuran Integrasi Alun-alun

Dari hasil pengukuran di atas, diketahui bahwa integrasi tertinggi dari kawasan alun-alun adalah pada dua jalan utama di sekitar alun-alun. Hal ini ditunjukkan pada garis warna merah sebagai ruang dengan integrasi tertinggi pada kawasan. Dua enklave budaya posisinya tidak jauh dari dua jalan utama tersebut. Sehingga secara global, kedua jalur sirkulasi ini memiliki probabilitas tinggi sebagai ruang interaksi antar dua komunitas ini dan komunitas budaya lokal di sekitarnya (di luar kedua enklave).

\section{PENUTUP}

\section{Simpulan}

Berdasarkan paparan di atas, dapat dipahami bahwa metode analisis Space syntax dapat menjadi salah satu alternatif cara untuk mengukur interaksi budaya di dalam kota. Interaksi tersebut dilihat melalui pergerakan manusia sebagai agency budaya di dalam struktur (structure) kota. 
Pengukuran konektivitas dalam Space syntax dilakukan dengan mengamati titik-titik kegiatan budaya berdasarkan waktu. Pada analisis ini, structure dan agency diamati melalui pergerakan setiap enklave budaya. Hasilnya merupakan nilai konektivitas bagi enklave dan antar enklave.

Pengukuran integrasi dalam Space syntax, menjadi upaya mengukur kesatuan kawasan secara keseluruhan. Analisis ini, menjadikan pusat kawasan dan enklave-enklave di sekitarnya sebagai area pengamatan. Hasilnya, nilai integrasi global tertinggi dari kawasan.

Penggunaan metode analisis ini, bukan hanya bermanfaat bagi cara pengukuran, melainkan cara lain memahami kota multibudaya dalam skala ruang dan praktik budaya. Dengan diketahuinya ruang-ruang interaksi antar budaya, dapat diarahkan pada pembentukan ruang terbuka baru yang mampu menjadi melting pot bagi pertemuan berbagai budaya di kota.

\section{DAFTAR PUSTAKA}

Amin, A. 2012. Land of Strangers. Cambridge: Polity Press.

Bridge, G., \& Watson, S. 2003. City Differences. In G. Bridge, \& S. Watson (Eds.), A Companion to the City (251-260). Oxford: Blackwell.

Carmona, Heath, Oc \& Tiesdell. 2003. Public places, urban spaces. Architectural Press.

Digby, B. 2006. Ethnic Enclaves in Large Cities. Geo Date, Vol 19 (3)

Giddens, Anthony. 1979. Central Problems in Social Theory: Action, Structure, and Contradiction in Social Analysis. University of California Press.

Hillier, B., \& Hanson, J. 1984. The Social Logic of Space. Cambridge, New York: Cambridge University Press.

Hillier B, Burdett R, Peponis J, \& Penn A. 1987. Creating life: or, does architecture determine anything? in Architecture and Behaviour, Vol 3 (3): 233-250

Hillier, B., et.al. 1993. Natural movement: or configuration and attraction in urban pedestrian movement. Environment and Planning B: Planning and Design, Vol 19: $29-66$

Hillier, B. 2007. Space is the machine. Space Syntax.
Lynch, Kevin. 1981. A Theory of Good City Form. London: Cambridge Mass, 73-98

Qadeer, Mohammad Abdul. 2016. Multicultural Cities: Toronto, New York, and Los Angeles. University of Toronto Press: Toronto Buffalo London

Sarraf, Mohammad. 2015. Spatiality of Multiculturalism. KTH Royal Institute of Technology. School of Architecture and the Built Environment. Stockholm, Sweden, 143-166

Siregar, Johannes Parlindungan. 2014. Metodologi Dasar Space Syntax Dalam Analisis Konfigurasi Ruang. Jurusan Perencanaan Wilayah dan Kota. Fakultas Teknik. Universitas Brawijaya.

Widmer, B. \& Klingele, M. 1998. Urban Enclaves: The New Urbanism and the City of Quartz. Cultural Identity and Spatial Segregation TAN2 Conference Report. Aarau, Switzerland.

Wilson, K. dan Portes, A. 1980. Immigrant Enclaves: An Analysis of The Labor Market Experiences of Cubans In Miami. American Journal of Sociology, Vol 86: 295-319

Daftar Pustaka dari Situs Internet (web site) :

UCL. Space Syntax, diperoleh melalui situs internet: http://otp.spacesyntax.net/. Diunduh pada tanggal 6 April 2019. 